\title{
Representing Canonical Texts in the Digital Age: the Case of the Estonian National Epic Kalevipoeg
}

\author{
Marin Laak \\ Estonian Literary Museum \\ marin.laak@gmail.com
}

Piret Viires

Tallinn University

viires@eki.ee

In this article ${ }^{1}$, our aim is to introduce the opportunities offered by digital media for the study and re-imaging of canonical literature. Under digital media we mean the combined effect of computer technology and the Internet. The development of technology is changing the way of thinking about literary texts, including literary canon. We would like to stress the fact that the technology definitely influences also literary research. The examples we give are related with the Estonian national epic Kalevipoeg, created in the $19^{\text {th }}$ century, the re-thinking of which started in an international work group of the EU Fifth Framework project "Cultural Units of Learning - Tools and Services". The goal of our article is to introduce the essence of research related to the CULTOS project and also to show how the ideas worked out during the project were developed further later.

CULTOS was a European Union Fifth Framework Information Society Technologies (IST) project, which was carried out in 20012003. ${ }^{2}$ The aim of CULTOS was to create new knowledge-aware

\footnotetext{
${ }^{1}$ The article has been written with the support of target financed research grants $\mathrm{nr}$ SF0030065s08 and SF0030054s08 and Estonian Science Foundation grants nr ETF7162 and ETF7679.

${ }^{2}$ See CULTOS homepage - http://www.cultos.org (15.12.2010).
} 
multimedia authoring and presentation tools for literary and cultural experts, and for the cross-media integration of cultural multimedia artefacts, using electronic environment. The leading partners were Salzburg Research Forschungsgesellschaft m.b.H. (Austria) and Tel Aviv University, The Porter Institute for Poetics and Semiotics (Israel). The content group worked under the leadership of Professor Ziva Ben-Porat. The authors of this article represented in this project the University of Tartu, Estonia.

The CULTOS project had an ambitious goal to create software for the formation of a universal relation network, which would function in a similar way to the human thinking process. The main task of the joint content group, working together with the technicians, was to develop a pluralistic and heterogeneous ontology of the intertextual relations and to provide the programme with a technologically suitable model for different types of relations. The theoretical framework was derived from the theory of transtextuality by Gérard Genette (1979, 1982, 1987, 1997), but was elaborated according to the needs of the CULTOS project. Genette's system of terminology was remade, and also some of the content group's own terms were introduced (cf. Benari 2003). The central notion in CULTOS project was an "intertextual thread" which was a new cultural unit, focusing on the way in which it may become a flexible, standard hypertextual format for creating and organizing multitextual webs (cf. Benari, Ben-Porat, Biberman, Chudnovsky, AmielHauzer, Segal 2004).

The technology applied in the CULTOS project, and the requirement to use multimedia material created certain preconditions for the original research by the content group. For example, content group members studied feminist reception of Jane Eyre in different media. The work group of Tel Aviv University mainly studied representations connected with the Bible and the intertextuality of the novel Don Quixote on different textual levels. 
The work group of Tartu University chose Kalevipoeg, the Estonian national epic created by Friedrich Reinhold Kreutzwald (1803-1879) in the 19th century, on the later waves of Enlightenment and Romanticism as the object of the research.

Folktales about Kalevipoeg were collected in the early 19th century and they formed the basis of the epic Kalevipoeg. The first publication of the epic Kalevipoeg was a scientific publication in Estonian and in German (Kreutzwald 1857-1861), a popular Estonian-language edition appeared the next year (Kreutzwald 1862). Kalevipoeg had a deep effect on the national awakening in the 19th century and became a symbol of freedom for Estonian nation. The epic emphatically centred on the myth of a hero in the characteristic manner of the European tradition of epic poems. At the same time, however, the hero's story symbolically reflects the wider idea of the the nation and its fight for freedom. All the deeds of the hero Kalevipoeg are related to the creation of his land. Although the hero perishes at the end of the epic, a hope remains that he will return one day and bring freedom and happiness to his people.

The literary reception of Kalevipoeg had so far considered its patriotic and historical, in a word - contextual meanings to be more important than its textuality. The reception had been related also to the concrete social and cultural space-time.

In our study, we had to re-think the previous context-centered research of Kalevipoeg and instead focus on the textuality of the epic. It was necessary to liberate the text from the cultural historical approach, which had dominated the earlier interpretations of Kalevipoeg. In order to visualise intertextual relations, the full text of the epic (32 000 verses), had to be split into motifs and small segments.

As the result of our analysis, we could state that the text of Kalevipoeg had become an important core text in Estonian culture as a whole (cf Laak 2003; Laak, Viires 2004, Laak 2008). Small textual pieces of Kalevipoeg can be seen on all cultural levels. Through 
Kalevipoeg, a large number of the intertextual motifs have acquired new and more powerful meanings in modern Estonian culture. Numerous motifs, themes, and concrete passages of text, originating from the epic have been interpreted and modified in modern Estonian literature and also non-literary art forms such as painting, drawing, pop-music, animations, cartoons, comics etc.

The preconditions of the CULTOS project required a two-way study of the intertextuality of Kalevipoeg. First, the study of older source texts, for which the text of Kalevipoeg was intertextual. Second, the reconstructive study of Kalevipoeg as a literary source text for later texts, starting from the newest texts (for example, comics, pop music, and postmodernist poetry).

Proceeding from the relations that branch into two directions, it was possible to create a dynamic hourglass model to represent all textual relations active in Kalevipoeg (cf Figure 1, see also Laak, Viires

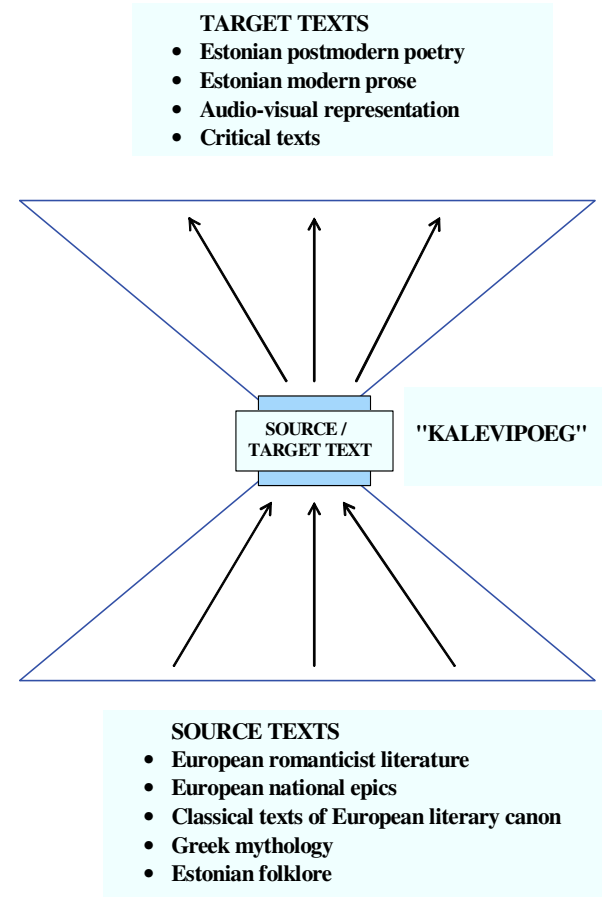

2004: 303).

Figure 1. The hourglass model of the epic 
The central part of the model is the text of Kalevipoeg. The lower part would show different intertextual relations between Kalevipoeg and the earlier texts, which would be its source texts. Several types of texts can be differentiated here: 1) literary source texts (e.g. Aeneid, Odyssey, Nibelungenlied, The Finnish epic Kalevala; 2) folk songs; 3) mythological icons; and, 4) international architexts $^{3}$ of folkloristic origin (e.g. perishing of a maiden, an orphan on his mother's grave, etc.)(cf also of Annist 1933; Oinas 1994).

The upper part of the hourglass consists of the contemporary Estonian literature, art, music and films. Here we would draw together all the texts that have either explicitly or implicitly used allusions, quotes or parodies, re-writing, etc. of Kalevipoeg.

We would like to stop briefly on this topic, the upper part of the hourglass, and give some examples.

Intertextual relations between Kalevipoeg and contemporary literature range from parodies to postmodernist games and Kalevipoeg has given rise to a surprisingly large number of postmodernist interpretations in Estonian literature. Searching for the reasons, we should recall Umberto Eco, who has found that postmodernist literature is characterised by "the loss of innocence", meaning that each word and sentence has already been said by somebody. In such a way, a postmodernist writer can write only in an ironic key. Eco argues that a postmodernist author finds that he cannot escape from the past, but that it can be represented and reused only in a non-innocent, ironic or parodic way. "Every story tells a story that has already been told" (Eco 1985: 19-20). And what could be a better story for postmodernist retelling than a national epic?

3 The notion is used according to the glossary of the CULTOS project. According to this, architext is a 'leading concept': "A conceptual or transcendent category (e.g. genre, style, topos) to which a Text or a Segment of a text is related and which might be relevant to its comprehension, interpretation and classification. 
The first parodies of Kalevipoeg emerged already in 1970s (eg. a parodic re-writing of the whole text of the epic titled "The Memoirs of Kalevipoeg" (Vetemaa 1971)), but a real boom in the use of motifs from Kalevipoeg occurred in the 1990s which brought along the sharpening of postmodernist features and the explosive growth of literary experiments. The subject of Kalevipoeg offered an object for playful interpretation for a number of Estonian writers, mostly for poets. An example here is from Contra's poem "Tarczani poeg" ("Tarczan's Son") (Contra 1998):

But one day an age will dawn when all spills, at both their ends,

will burst forth into flame;

and this stark fire will sever

the vise of stone from Kalevipoeg's hand. Then the son of Kalev will come home -

to bring his children happiness and build Estonia's life anew.

Kalevipoeg, 20th song (1861) (Translated by Jüri Kurman; Kreutzwald 1982: 266)
But one day time will come when ransom money will be raised

Tarzan will come home pockets full of dough he will free his son soon visas will be abolished then Tarzan will come home

to bring happiness to the jungle people

to drink beer in the yard of happiness

Contra "Tarczan's Son"

(Contra 1998: 32)

Here, we are dealing with a double re-writing, the texts about the hero Tarzan and the hero Kalevipoeg are intermingled, intertextual referrals are mixed with referrals to modern everyday life. 
Besides Estonian writers who have re-written Kalevipoeg, there exist also a lot of parodies in the Internet written by amateur authors. That proves the topicality and the symbolical value of Kalevipoeg in the whole Estonian cultural space up to now.

Thus we can state that Kalevipoeg is continuously topical for contemporary Estonian writers and that Kalevipoeg as one of the core texts of Estonian culture offers many opportunities for postmodernist games and experiments. Kalevipoeg is the story that is retold again and again.

So, returning again to the hourglass model, we can argue that according to such a model, the meaning of Kalevipoeg as a text would be constructed through the smaller units of texts that generate intertextual relations.

We can, thus, assert that Kalevipoeg as a source text has intratextually generated only the accumulation and/or amplification of certain motifs and themes. Among such motifs are, for example mourning, journey, hope, hell, maiden, fate, and bard. In the epic, these motifs can be conveyed by small textual units, as well as by longer passages of text. Analyzing these units we discovered that the basis of them is the intra-textual structure of the epic: these units and certain themes are cyclically hierarchically repeated within the whole text of the epic. So, the meaning of Kalevipoeg manifests itself particularly through the choice of motifs that have inspired numerous modern texts since the 19th century.

So, in conclusion, what were the main results in the study of the epic Kalevipoeg? What did the participation in the CULTOS project give us?

1. The study of the epic required the rejection of earlier interpretations, a certain deconstruction and re-imaging of the epic's text. The task of pointing out intertextual relations based on 
small textual units - required the changing of the previous focus. The macro-level of the epic as a great narrative was replaced by the textual micro-level.

2. The textual representation of Kalevipoeg in an electronic environment required the creation of new knowledge models and new cultural units - the intertextual threads (example of the thread cf. Figure 3). They are structured as non-linear networks, each of which is based on a segment or motif that carries a certain meaning. For example, one such thread may relate the representation of one and the same motif in a) postmodernist texts, $b$ ) in the romantic and patriotic poem from the period of national awakening, c) Kalevipoeg as a source text and d) the architext belonging to the Western canon like Odysseia

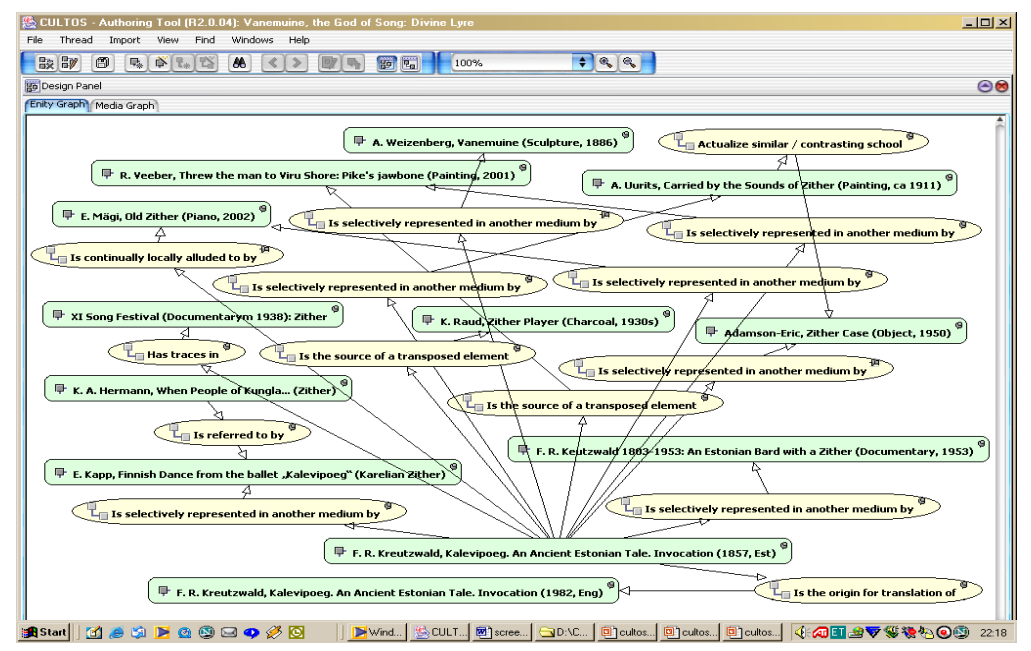

Figure 2. Screenshot of the IT-thread "Vanemuine, the God of Song: Modern Interpretations"

3. The study of Kalevipoeg that proceeded from the aims of computer technology yielded results that had never been defined in the previous research of the epic. The whole text of the epic has transcended in the later layers of Estonian culture, but 
only in small textual fragments - phrases, utterances, fragments, motifs, subjects - , which have been given different meanings by different authors in different periods.

4. Such results led to a hypothesis that the intertextuality generated by Kalevipoeg is connected with the intra-textual relations of the epic which was confirmed by our study.

5. And finally, we can argue, that without the preconditions determined by the CULTOS project and the technology that forced us to read the epic Kalevipoeg in a new way, we assume that we had not achieved the research results described above.

The CULTOS project came to an end in 2003, but its ideas were developed further in another project in Estonia. In 2004 a huge cultural historical web project was started with the title Kreutzwald's Century: the Estonian Cultural History Web, that is still in progress.( http://kreutzwald.kirmus.ee) Kreutzwald's Century is a knowledge environment that represents Estonian cultural and literary history from the 19th century up to the beginning of the 20th century. The project has been deeply influenced by the CULTOS project and the idea of semantic relations between the digitized objects. Using five dynamic temporal axis the idea of the project has been to introduce the text of the epic Kalevipoeg and the life of the author F. R. Kreutzwald in the context of the works of the canonical Estonian and European writers and Estonian social and cultural history. The reader can compare the text of the epic and the intertextually related modern poems, also some fine arts and music texts, which were all collected during the CULTOS project.

The aim of the project was to create an interactive environment combining a new user-friendly interface and unique software tools that 
enable to construct the historical content environment with internal semantic relations. For this project, we digitised the sources held at the archives and library of the Estonian Literary Museum (rare books of the classic authors, manuscripts and photos) and also added a lot of supplementary information. The digitised cultural sources are linked with biographical data of the writers. So, the user can read a writer's texts and also browse his texts, books, manuscripts, documents and photo collections. The general idea of the project was to construct a cultural historical space based on the macro elements of cultural history narrative (cf also Laak 2006).

We could say that the newest challenge is to "translate" the literary history as a linear narrative into the non-linear form. Although the past has not changed, every generation has to rewrite the narrative literary history so that the past remains understandable for the changing present. In our opinion, this would be the most important aspect in order to maintain the coherence of cultural memory.

As the final conclusion we can pose the question: will the computational media become the new basis of the 21st century historiography? We can conclude that rewriting the literary past and reinterpretation literary canon in the digital era requires deconstruction of the "traditional" image of the classics in order to show smaller units (such as events, objects, persons, texts). Using these units, we can represent the past in a new way, integrating the possibilities of the computational media and also the general idea offered by new cultural history. 


\section{References}

August 1933. "Kalevipoja" eelkäijad ja paralleele Kesk- ning PõhjaEuroopas. - Eesti Kirjandus, nr 9, Ik 401-412.

BENARI, Motti 2003. Glossary of Terms from the Concepts' Hierarchy. Proposal for a Standard Ontology of Intertextuality. CULTOS-IST-200028134. Public Deliverable 3.3.2.

BENARI, Motti; Ben-Porat, Ziva; Biberman, Efrat; Chudnovsky, Liza; Amiel-Hauzer, Tammy; Segal, Eyal 2004. The Intertextual Thread: A New Cultural Unit in Hypertext. - Leonardo Electronic Almanac. Vol. 12, nr 9, September. http://lea.mit.edu (6. 12.2010)

Contra 1998. Tarczan. Võru: Contra.

ECO, Umberto 1985. Reflections on "The Name of the Rose". London: Secker and Warburg.

GENETTE, Gérard 1979. Introduction à l'architexte. Paris: Éditions du Seuil.

GENETTE, Gérard 1982. Palimpsestes. Paris: Éditions du Seuil.

GENETTE, Gérard 1987. Seuils. Paris: Éditions du Seuil.

GENETTE, Gérard 1997. Paratexts: Thresholds of Interpretation. Trans. J. E. Lewin. Cambridge: Cambridge University Press.

KREUTZWALD, F. R. 1857-1861. Kalewipoeg, eine Estnische Sage. Verhandlungen der gelehrten Estnischen Gesellschaft zu Dorpat, Bd. 4, Heft 1-4; Bd. 5, Heft 1-2/3. http://kreutzwald.kirmus.ee/et/kalevipoeg KREUTZWALD, F. R. 1862. Kalewi poeg: üks ennemuistene Eesti jut: kaheskümnes laulus. Võru: F. R. Kreutzwald. http://kreutzwald.kirmus.ee/et/kalevipoeg 
KREUTZWALD, F. R. 1982. Kalevipoeg. An Ancient Estonian Tale. Trans by J. Kurman. Moorestown, New Jersey: Symposia Press.

LAAK, Marin 2003. Monument vs alustekst: "Kalevipoja" retseptsioonist ja intertekstuaalsusest. - Paar sammukest. Eesti Kirjandusmuuseumi aastaraamat. Tartu: Eesti Kirjandusmuuseum, Ik 129-142.

LAAK, Marin 2006. Kalevipoeg hargnevate teede aias: kirjandusajaloo "kirjutamine" uue meedia keskkonnas. - Paar sammukest XXII. Eesti Kirjandusmuuseumi aastaraamat. Tartu Eesti Kirjandusmuuseum, Ik $219-238$.

LAAK, Marin 2008. "Kalevipoeg as a Core Text: the Island Maiden's Thread" - Interlitteraria, No 13, pp. 19-213.

LAAK, Marin; Viires, Piret 2004. Intertextuality and Technology: The Models of "Kalevipoeg". - Intertextuality and Intersemiosis. Eds. M. Grishakova; M. Lehtimäki. Tartu: Tartu University Press, pp. 284-312. OINAS, Felix 1994. Surematu Kalevipoeg. Järelsõna Jaan Undusk. Keele ja Kirjanduse raamatusari nr 1. Tallinn: Keel ja Kirjandus.

VETEMAA, Enn 1971. Kalevipoja mälestused. - Looming, $\mathrm{nr} 11$, Ik 1619-1671; nr 12, Ik 1763-1820. 